\title{
Geochemistry of eolian dust in Pacific pelagic sediments: Implications for paleoclimatic interpretations
}

\author{
Annette M. Olivarez, ${ }^{1}$ Robert M. Owen, ${ }^{2, *}$ and David K. ReA ${ }^{2}$ \\ 'Department of Earth Sciences, The University of Notre Dame, Notre Dame, IN 46556, USA \\ ${ }^{2}$ Department of Geological Sciences, The University of Michigan, Ann Arbor, MI 48109, USA
}

(Received December 15, 1989; accepted in revised form May 10, 1991)

\begin{abstract}
Geochemical data (REEs, Th, Sc) were determined for the operationally defined eolian dust (ODED) fraction $(<63 \mu \mathrm{m})$ of Late Quaternary sediment samples $(\mathrm{n}=57)$ from the north and equatorial Pacific Ocean. Paleoclimate studies commonly have assumed that this sediment fraction represents eolian materials from continental source regions. This study shows, on the basis of geochemical data, published mineralogical data, and mixing models, that the ODED fraction actually is a mixture of materials from two endmember sources: the continental crust (eolian-transported weathering products) and the oceanic crust (primarily volcanogenic material). Mixing model results show that the average ash content is significant in the ODED fraction (equatorial Pacific $=43 \%$; north Pacific $=24 \%$ ). We have used this information to reconsider and refine the results of previous paleoclimate studies. In the northwest Pacific the flux of the eolian fraction is greater during glacial stages and shows a latitudinal maximum between $35^{\circ} \mathrm{N}$ and $42^{\circ} \mathrm{N}$. Eolian fluxes are greatest during interglacial periods in the equatorial Pacific. These results are consistent with previous interpretations. In contrast to previous assumptions, eolian mass accumulation rates may not be a valid indicator of paleo-aridity because they are correlated with grain size. Furthermore, the relative abundance of the two endmembers is correlated with the average grain size of the dust fraction (the continental crust component is associated with larger grains). This compositional effect should be considered in future studies which commonly utilize grain size as a proxy indicator of paleo-wind intensity.
\end{abstract}

\section{INTRODUCTION}

VARIOUS CATEGORIES OF DATA (e.g., oxygen isotopes) from the marine sedimentary record have been used as proxy indicators of paleoclimate. Among these is the record of eolian dust, which is a significant component of marine pelagic sediments (GRIFFIN et al., 1968; WINDOM, 1969, 1976; FERGUSON et al., 1970; BLANK et al., 1985). Paleoclimatic interpretations on time scales ranging from $10^{3}$ to $10^{8}$ years have been made based on the analysis of mineral grains which are presumably produced by the weathering of continental crust and subsequently transported by surface winds and incorporated into pelagic sediments (e.g., REA et al., 1985). For example, particle size (median grain diameter) is used as a proxy indicator of wind velocity, whereas variations in the flux or mass accumulation rate (MAR) of pelagic dust can provide information on the aridity or vegetative cover on the continents (PROSPFRO, 1981).

The development of paleoenvironmental reconstructions from the analysis of eolian materials requires the separation of the eolian component from the bulk sediment assemblage. This is a critical step, inasmuch as the reliability of subsequent interpretations depends upon the efficacy of this procedurc. The laboratory method commonly used to achieve this separation involves subjecting the bulk sediment to a sequential chemical extraction scheme, each stage of which is intended to remove some portion of the non-eolian components. The mass fraction which remains after these extractions is then regarded as the operationally defined eolian dust (ODED) component of the sediments (e.g., REA and JANECEK, 1981). We emphasize the term "operationally defined" because there

\footnotetext{
* Author to whom correspondence should be addressed.
}

is no chemical or mineralogical technique which provides a complete and unambiguous separation of eolian and noneolian sediment components. For example, if measurements of the ODED fraction are to serve as proxy indicators of paleoclimate, then the extraction residue should consist exclusively of mincral grains which have becn produced by the weathering of cratonic continental crust (e.g., loess) and transported by eolian processes. In practice, however, it is recognized that this ideal separation is not always achieved, because certain non-eolian and/or non-continental materials (e.g., authigenic clays, continentally derived hemipelagic sediments, ice-rafted debris, and volcanic ash) can survive the chemical extraction procedure (REA, 1982). It is possible to minimize the presence of some of these "contaminants" in the ODED fraction by avoiding sampling from geographic locations which are influenced by hemipelagic sedimentation, turbidite sedimentation, and ice rafting (REA et al., 1985). Even if one adheres to this sampling strategy, however, there remains the possibility of contamination by wind-transported volcanic ashfall and other non-continental erosion products. This problem may be significant in paleoclimate studies, because the presence of such contaminants in the ODED fraction may affect measurements of the MAR and grain-size distribution of this fraction; yet variations in grain-size or flux of these components are presumably unrelated to changes in paleoclimate.

The goal of the present study is to demonstrate that a significantly improved separation of the continental and noncontinental portions of the ODED fraction can be achieved through the application of geostatistical modelling techniques. The samples analyzed here are taken from the same Pacific Ocean sediment cores from which previous analyses of the MAR and median grain-size of the ODED fraction have been 
used to develop paleoclimatic interpretations (CHUEY et al., 1987; JANECEK and REA, 1985; LEINEN, 1989; REA, 1982; REA and JANECEK, 1981; REA et al., 1986). The approach used here involves a geochemical analysis of the ODED fraction isolated from these samples, followed by a statistical analysis of the geochemical data to determine the number, estimated composition, and relative amount of different compositional endmembers that are present within the ODED fraction. Finally, the corrected data resulting from these procedures are used to re-evaluate previous paleoclimate interpretations.

\section{SAMPLE DESCRIPTION AND METHODS}

We have analyzed 57 samples of marine sediment obtained from coring in the north Pacific ( 31 samples from 12 sites) and cquatorial Pacific (26 samples from 3 sites). Nearly all of these locations (Fig. 1) are considered to receive a minimal amount of non-eolian continental material (REA and JANECEK, 1981; REA et al., 1985), except for the three samples obtained from Site V19-29. The latter three samples may contain a significant ash component from andesitic and rhyolitic volcanism of Southern Mexico, Central America, and South America (e.g., LEDBETTER, 1985), and they are included here because their REE geochemistry may reflect this volcanic source. To estimate the effect of the chemical extraction procedure upon continentally derived eolian material, three samples of loess from the Lanzhou region of China were also analyzed. The mineralogy of China loess, northwest Pacific sediments, and the equatorial Pacific sediments has been described elsewhere (LEINEN, 1989; ZHENG HONG-HAN, 1984; ZIMMERMAN, 1982) and is discussed in the following sections.

The ODED fraction of loess and all sediment samples were isolated from the bulk sediment using a conventional laboratory procedure which involves a series of chemical and physical separations, each intended to remove (via dissolution and subsequent filtration) noneolian components. A detailed description of this procedure is given in REA and JANECEK (1981), so it is only briefly summarized here. Calcium carbonate is removed using a $25 \%$ acetic acid solution; oxides, hydroxides, and zeolites are removed with a solution of sodium dithionite-sodium citrate buffered with sodium bicarbonate; and finally, opal is removed using warm sodium carbonate baths. The solid residue remaining after these dissolution steps is then sieved through a 63 $\mu \mathrm{m}$ mesh screen to remove the coarsest remaining material (commonly ash and resistant radiolaria), and that fraction which passes through the screen (i.e., the ODED fraction) is rinsed and freezedried prior to further analyses.
Geochemical analysis of the ODED fraction was determined by instrumental neutron activation analysis (INAA) at the Phoenix Memorial Laboratory, The University of Michigan. Approximately 150 $\mathrm{mg}$ of dry sample was placed in a polyethylene micro-vial and analyzed for the elements $\mathrm{La}, \mathrm{Ce}, \mathrm{Sm}, \mathrm{Eu}, \mathrm{Yb}, \mathrm{Lu}, \mathrm{Sc}$, and Th using standard INAA procedures (GORDON et al., 1968; DAMS and ROBBINS, 1970). Sediment from two or more adjacent sample intervals were combined for cores RC11-210 and DSDP Site 503B to achieve the minimum mass required for geochemical analysis. However, samples from glacial periods were never mixed with those from interglacial periods. NBS sediment standard SRM-1633-A was included in each sample batch as a check on the accuracy of the INAA results. All geochemical data for both samples and standards are summarized in Table 1. Statistical analyses of the resulting chemical data were performed using MIDAS, a package of computer programs provided by the Statistical Research Laboratory at The University of Michigan (FoX and GUIRE, 1976), using the Q-Mode factor analysis procedure of LEINEN and PISIAS (1984), and using the normative analysis method of DYMOND (1981).

\section{RESULTS AND DISCUSSION}

\section{REE Patterns}

To account for both latitudinal and longitudinal variations which may be present, and to simplify the presentation of the data, north Pacific samples were assigned to one of two major groups (Table 1): (1) a north-south transect of samples which fall between a longitudinal band from $140^{\circ} \mathrm{E}$ and $160^{\circ} \mathrm{E}$ in the northwest Pacific (Sites V20-122, V20-126, RC14-105, V20-129, and V28-294); and (2) an east-west transect of samples which fall within a latitudinal band between $30^{\circ} \mathrm{N}$ and $46^{\circ} \mathrm{N}$ (Site V32-128, GPC3, W8209-B, and TT-175-83P). Samples from the equatorial Pacific are identified on the basis of their respective core locations.

Shale-normalized (GROMET et al., 1984) REE patterns (Fig. 2) of loess obtained from different continents are remarkably similar and, overall, representative of the upper continental crust (TAYLOR et al., 1983; TUNGSHENG et al., 1985). The REE patterns of both chemically treated and untreated samples of China loess (Fig. 2) fall within the range defined by globally distributed loess samples from America, China, and New Zealand (TAYLOR et al., 1983). The slightly lower REE concentrations in the treated sample probably reflect the

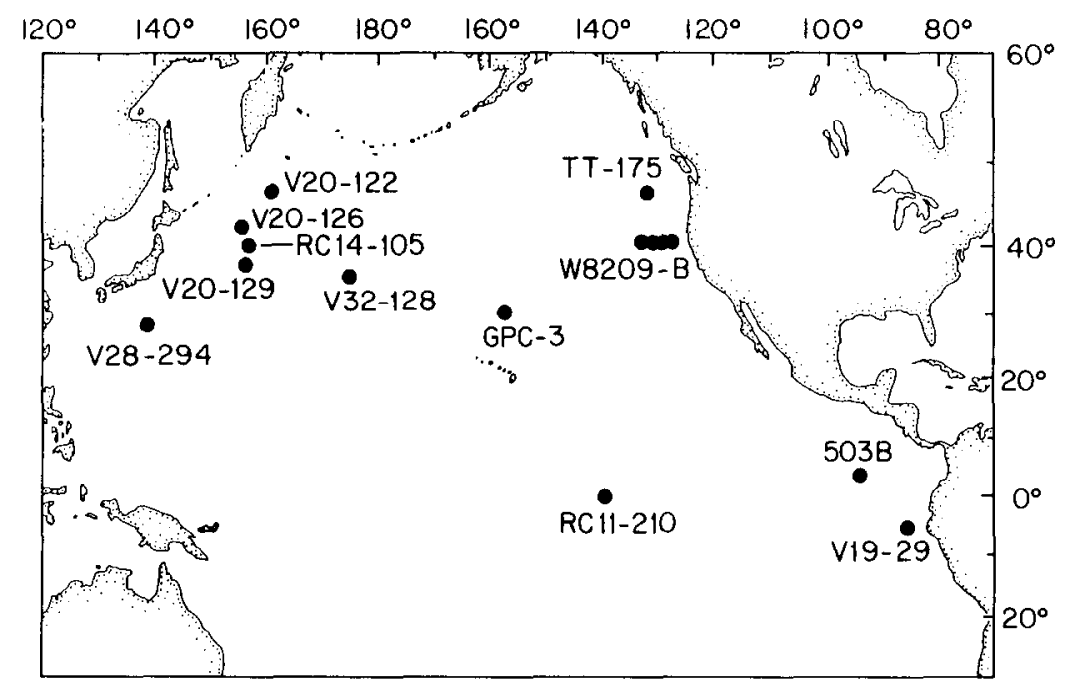

FIG. 1. Site locations of samples used in this study. 
Table 1. Geochemical data for Pacific sediment, China loess (CLoess), and NBS sediment standard. Site ID codes are as follows: $1=$ Core RC11-210; 2 = DSDP Site 503B; $3=$ northwest Pacific sediment (north-south transect); $4=$ north Pacific sediment (east-west transect.); 5 = Core V19-29; 6 = China Loess. Glacial stage codes: $1=$ glacial, $2=$ interglacial. All pacific sediment data and Cloess-x pertain to the extracted (ODED) fraction. CLoess-NX-1 and $-\mathrm{NX}-2$ were not extracted. Dashed lines for geochemical data indicate values below detection limits.

\begin{tabular}{|c|c|c|c|c|c|c|c|c|c|c|c|}
\hline Sample ID & $\begin{array}{l}\text { Depth } \\
(\mathrm{cm})\end{array}$ & $\begin{array}{l}\text { site } \\
\text { ID }\end{array}$ & $\begin{array}{l}\text { Glacial } \\
\text { Period }\end{array}$ & $\begin{array}{c}\mathrm{La} \\
(\mathrm{ppm})\end{array}$ & $\underset{(\mathrm{ppm})}{\mathrm{Ce}}$ & $\begin{array}{c}\mathrm{Sm} \\
(\mathrm{ppm})\end{array}$ & $\begin{array}{c}\text { Eu } \\
(\mathrm{ppm})\end{array}$ & $\begin{array}{c}Y \mathrm{~b} \\
(\mathrm{ppm})\end{array}$ & $\begin{array}{c}\mathrm{Lu} \\
\text { (ppm) }\end{array}$ & $\begin{array}{c}\mathrm{Sc} \\
(\mathrm{ppm})\end{array}$ & $\begin{array}{c}\text { Th } \\
\text { (ppm) }\end{array}$ \\
\hline $\operatorname{RC} 11-210: 135-256$ & 195 & 1 & - & 8.47 & 18.3 & 1.28 & 0.40 & -- & -- & 10.3 & 3.34 \\
\hline RC11-210:264-304 & 284 & 1 & 2 & 13.7 & 27.5 & 1.95 & 0.65 & -- & -- & 20.1 & 4.68 \\
\hline RC11-210:312-400 & 356 & 1 & 1 & 11.5 & 22.4 & 1.42 & 0.41 & -- & -- & 15.3 & 3.89 \\
\hline RC11-210:408-472 & 440 & 1 & 2 & 10.6 & 22.6 & 1.58 & 0.43 & -- & -- & 15.5 & 3.92 \\
\hline $\mathrm{RC} 11-210: 480-544$ & 512 & 1 & 1 & 7.50 & 15.5 & 1.22 & 0.26 & -- & -- & 11.7 & 3.20 \\
\hline $\mathrm{RC} 11-210: 552-608$ & 580 & 1 & 2 & 11.3 & 23.7 & 1.52 & 0.42 & -- & -- & 15.8 & 3.74 \\
\hline RCII-210:616-720 & 668 & 1 & 1 & 9.91 & 18.1 & 1.40 & 0.39 & -- & -- & 14.4 & 4.50 \\
\hline RCl1-210:728-816 & 772 & 1 & - & 7.83 & 13.9 & 1.03 & 0.20 & -- & -- & 22.5 & 3.52 \\
\hline RC11-210:824-880 & 852 & 1 & - & 8.43 & 15.2 & 1.16 & 0.38 & -- & -- & 34.3 & 2.70 \\
\hline RC11-210:888-1008 & 948 & 1 & 1 & 7.81 & 16.3 & 1.15 & 0.42 & -- & -- & 14.8 & 3.03 \\
\hline $\mathrm{RC} 11-210: 1016-1064$ & 1040 & 1 & - & 8.95 & 14.4 & 1.22 & 0.34 & -- & -- & 10.9 & 3.11 \\
\hline RC11-210:1072-1136 & 1104 & 1 & - & 8.98 & 10.7 & 1.14 & 0.32 & -- & -- & 11.1 & 2.62 \\
\hline RCl1-210:1144-1200 & 1172 & $i$ & 1 & 9.95 & 18.7 & 1.38 & 0.33 & -- & -- & 22.8 & 4.26 \\
\hline RCI1-210:1208-1280 & 1244 & 1 & - & 9.14 & 16.7 & 1.40 & 0.35 & -- & -- & 23.0 & 3.45 \\
\hline RC11-210:1288-1328 & 1308 & 1 & - & 6.90 & 13.2 & 1.19 & 0.36 & -- & -- & 14.9 & 3.56 \\
\hline$R C 11-210: 1336-1376$ & 1356 & 1 & - & 9.46 & 17.9 & 1.41 & 0.43 & -- & 0.23 & 18.1 & 3.50 \\
\hline $503 B-57$ & 57 & 2 & 1 & 15.3 & 27.2 & 2.39 & 0.49 & 1.2 & 0.29 & 24.2 & 4.00 \\
\hline $503 \mathrm{~B}-116.5$ & 116.5 & 2 & 2 & 13.9 & 20.5 & 2.12 & 0.54 & -- & - & 21.7 & 5.41 \\
\hline $503 \mathrm{~B}-196 \mathrm{a}$ & 196 & 2 & 1 & 13.6 & 24.2 & 2.12 & 0.65 & -- & 0.22 & 27.3 & 4.13 \\
\hline $503 B-196 b$ & 196 & 2 & 1 & 14.4 & 25.3 & 2.09 & 0.54 & 1.1 & -- & 27.5 & 4.30 \\
\hline $503 B-306$ & 306 & 2 & 2 & 15.6 & 28.9 & 2.48 & 0.59 & 1.5 & 0.20 & 20.7 & 5.73 \\
\hline $503 B-398$ & 398 & 2 & 2 & 11.6 & 23.4 & 2.09 & 0.49 & 1.4 & -- & 33.0 & 3.39 \\
\hline $503 B-474$ & 474 & 2 & 1 & 15.4 & 27.2 & 2.38 & 0.69 & 1.4 & 0.21 & 25.3 & 4.17 \\
\hline $503 B-518$ & 518 & 2 & 2 & 12.9 & 24.5 & 2.21 & 0.79 & - & - & 31.3 & 3.39 \\
\hline $\mathrm{V} 20-122: 10$ & 10 & 3 & 2 & 12.3 & 28.1 & 2.58 & 0.79 & 2.2 & 0.28 & 18.0 & 3.06 \\
\hline$v 20-122: 27$ & 27 & 3 & 2 & 12.9 & 27.0 & 2.78 & 0.80 & 2.3 & 0.32 & 21.3 & 3.86 \\
\hline V20-122:80 & 80 & 3 & 1 & 20.4 & 42.7 & 3.39 & 0.86 & 2.4 & 0.32 & 17.5 & 5.79 \\
\hline V20-122:107 & 107 & 3 & $\overline{1}$ & 20.1 & 47.3 & 3.37 & 0.85 & 2.6 & 0.31 & 16.8 & 5.51 \\
\hline v20-126:18.5a & 18.5 & 3 & 2 & 15.0 & 32.5 & 2.86 & - & 3.5 & 0.35 & 16.4 & 4.44 \\
\hline$v 20-126: 41.5 b$ & 41.5 & 3 & 2 & 13.2 & 29.2 & 2.72 & 0.57 & 2.7 & 0.41 & 13.8 & 3.83 \\
\hline V20-126:115a & 115 & 3 & 1 & 13.6 & 34.6 & 3.44 & -- & 3.7 & 0.54 & -- & 3.75 \\
\hline$v 20-126: 115 b$ & 115 & 3 & 1 & 13.9 & 35.1 & 3.46 & -- & 3.0 & 0.48 & -- & 3.73 \\
\hline$V 20-126: 149$ & 149 & 3 & 1 & 20.0 & 43.8 & 3.29 & -- & 3.1 & 0.31 & -- & 6.26 \\
\hline RC14-105:11a & 11 & 3 & 2 & 21.2 & 43.5 & 3.27 & 0.98 & 2.7 & 0.26 & 16.4 & 6.38 \\
\hline $\mathrm{RC} 14-105: 34.5$ & 34.5 & 3 & 2 & 15.1 & 30.7 & 3.76 & 0.72 & 3.5 & 0.64 & 12.0 & 4.42 \\
\hline RC14-105:111a & 111 & 3 & 1 & 26.0 & 53.1 & 3.68 & 0.85 & 2.4 & 0.35 & 15.7 & 7.90 \\
\hline RC14-105:147 & 147 & 3 & 1 & 25.9 & 52.5 & 3.60 & -- & 3.2 & 0.30 & 16.0 & 7.80 \\
\hline $\mathrm{V} 20-129: 11 \mathrm{a}$ & 11 & 3 & 2 & 21.5 & 47.6 & 5.19 & 0.78 & 3.1 & 0.79 & 16.9 & 6.94 \\
\hline V20-129:45a & 45 & 3 & 2 & 20.8 & 43.0 & 2.95 & 0.67 & 1.9 & 0.22 & 19.9 & 6.70 \\
\hline V20-129:139.5a & 139.5 & 3 & 1 & 26.0 & 49.7 & 3.74 & 0.75 & 2.2 & 0.49 & 16.1 & 7.40 \\
\hline V20-129:185 & 185 & 3 & 1 & 24.4 & 51.9 & 3.36 & -- & 2.5 & 0.32 & 16.9 & 6.99 \\
\hline$V 28-294: 1$ & 1 & 3 & 2 & 11.5 & 31.4 & 2.76 & 0.79 & 2.5 & 0.32 & 21.9 & 3.74 \\
\hline V28-294:16a & 16 & 3 & 2 & 18.5 & 37.3 & 3.19 & 0.78 & 2.5 & 0.46 & 19.4 & 5.33 \\
\hline V32-128:10 & 10 & 4 & - & 36.2 & 83.2 & 5.21 & 1.07 & 2.9 & 0.47 & 15.8 & 10.5 \\
\hline V32-128:21 & 21 & 4 & - & 31.8 & 73.6 & 4.51 & 0.94 & 3.2 & 0.36 & 14.8 & 8.93 \\
\hline$G P C 3-50833$ & -- & 4 & - & 30.5 & 59.6 & 4.01 & 0.81 & 2.5 & 0.35 & 16.1 & 8.34 \\
\hline W8209B-1GC-a & 1 & 4 & - & 19.5 & 40.1 & 2.83 & 0.82 & 1.9 & 0.29 & 14.0 & 5.88 \\
\hline W8209B-1GC-b & 1 & 4 & - & 18.6 & 40.3 & 2.78 & 0.71 & 2.4 & 0.35 & 15.1 & 6.41 \\
\hline W8209B-10GC-a & 10 & 4 & - & 18.4 & 36.9 & 2.55 & 0.70 & 2.6 & 0.36 & 17.5 & 6.21 \\
\hline W8209B-10GC-b & 10 & 4 & - & 16.1 & 35.7 & 2.35 & 0.72 & 1.6 & 0.31 & 16.7 & 5.75 \\
\hline W8209B-19GC-a & 19 & 4 & - & 16.6 & 39.3 & 2.34 & 0.75 & 2.1 & 0.25 & 18.0 & 5.91 \\
\hline$W 8209 \mathrm{~B}-19 \mathrm{GC}-\mathrm{b}$ & 19 & 4 & - & 17.4 & 39.2 & 2.47 & 0.75 & 1.9 & 0.28 & 18.2 & 6.09 \\
\hline W8209B-21GC & 21 & 4 & - & 20.0 & 47.0 & 2.74 & 0.83 & 2.2 & 0.37 & 18.1 & 6.00 \\
\hline TT 67476 & -- & 4 & - & 21.5 & 42.2 & 3.66 & 0.94 & 2.4 & 0.33 & 23.8 & 6.21 \\
\hline $\operatorname{TT} 67477$ & -- & 4 & - & 25.0 & 53.1 & 1.51 & 1.05 & 2.3 & 0.29 & 19.7 & 7.18 \\
\hline V19-29:2.5 & 2.5 & 5 & - & 12.0 & 24.7 & 1.90 & 0.60 & 1.2 & 0.22 & 19.6 & 4.32 \\
\hline V19-29:132 & 132 & 5 & - & 8.96 & 17.8 & 1.68 & 0.34 & 1.1 & 0.14 & 16.7 & 3.81 \\
\hline CLoess-X & -- & 6 & - & 31.4 & 69.5 & 4.92 & 0.98 & 2.8 & 0.37 & 10.6 & 10.2 \\
\hline CLoess-NX-1 & -- & 6 & - & 35.3 & 69.8 & 5.99 & 1.22 & 2.8 & 0.39 & 10.6 & 12.8 \\
\hline CLoess-NX-2 & -- & 6 & - & 34.0 & 72.2 & 5.72 & 1.16 & 2.8 & 0.36 & 10.5 & 11.8 \\
\hline \multicolumn{12}{|l|}{ NBS-SRM-2633-A: } \\
\hline Expected: & & & & 83 & 175 & 17 & 3.5 & 8.2 & 1.1 & 38 & 24.7 \\
\hline $\begin{array}{l}\text { Measured: } \\
\text { (avg. }, n=2 \text { ) }\end{array}$ & & & & 82 & 181 & 17 & 3.2 & 8.4 & 1.2 & 30 & 25.8 \\
\hline
\end{tabular}


dissolution of minor amounts of REEs in ion exchange positions or associated with surface coatings on the loess; however, this comparison suggests the chemical extraction procedure does not alter the characteristic pattern of lattice-held REEs in continentally derived eolian source materials. Inasmuch as the Pacific sediment samples were subjected to the same chemical extraction procedure, we would expect their REE patterns to be similar to loess if the ODED fractions of the samples are representative of upper crustal (i.e., continental) eolian mincral assemblages (REA and JANECEK, 1981; REA et al., 1985). However, a comparison of the REE patterns of the loess and sediments reveals significant differences in detail and in overall REE abundance (Fig. 3). Compared to loess, $\mathrm{Ce}$ is relatively depleted, the overall REE pattern is relatively flatter in the sediments, and the shale-normalized $\mathrm{Eu}_{\mathrm{n}} / \mathrm{Sm}_{\mathrm{n}}$ ratios of the sediments are all $>1$, whereas for loess this ratio is $<1$. The most pronounced differences are that all the sediment samples are markedly depleted in the light RFFs relative to loess, and there is a relatively greater degree of REE depletion in the equatorial samples compared to the north Pacific samples.

It is unlikely that the observed REE depletion in the sediment samples relative to loess is simply an artifact of the chemical extraction procedure. This possibility would be a concern if the mineralogy of the sediment samples included a greater proportion of clay minerals that have relatively high cation exchange capacities (e.g., smectite and illite), such that a greater proportion of REEs may have been leached during the extraction process. However, the mineralogy of China loess is dominated by sub-equal amounts (about $35 \%$ of each) of smectite and illite, and the fraction of these clay minerals in loess is actually greater than in the ODED fraction of Pacific sediments (LEINEN, 1989). On the other hand, mineralogical

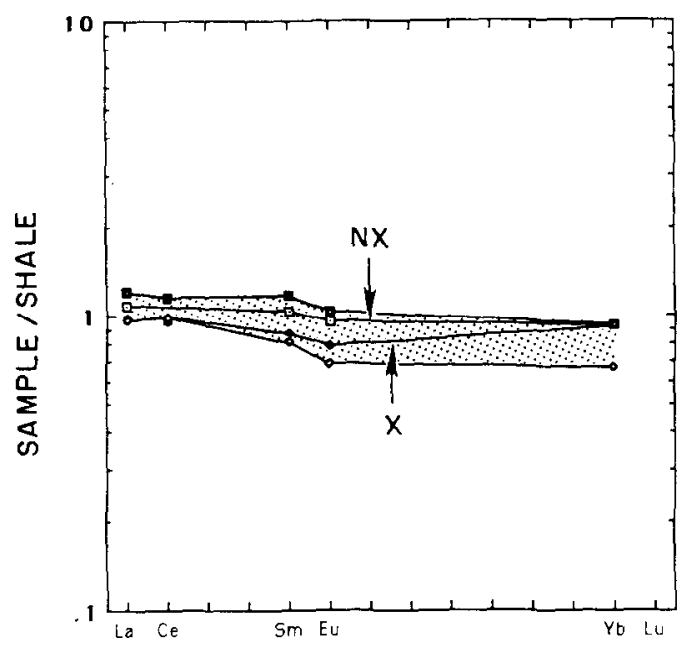

FIG. 2. Shale-normalized (GROMET et al., 1984) REE patterns of China loess samples analyzed in this study relative to the range (shaded region) of observed patterns for loess from different continents (data from TAYLOR et al., 1983; upper bound = Nanking, lower bound $=$ Kansas B). $\mathrm{X}=$ China loess, chemically treated; $\mathrm{NX}=$ China loess, untreated. Note: China loess falls within the range expected for loess samples and is relatively unaffected by the extraction procedure.

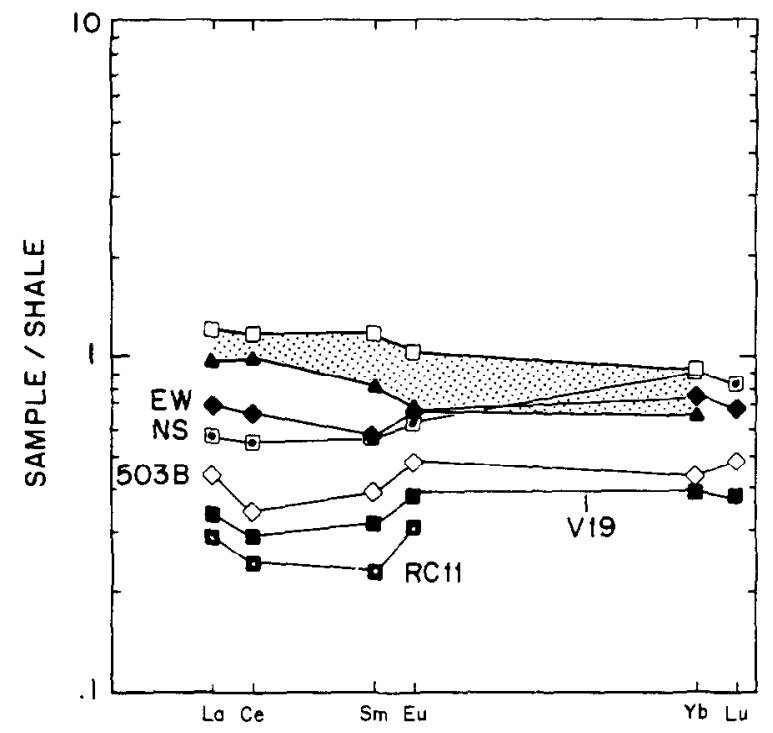

FIG. 3. Shale-normalized (GROMET et al., 1984) REE patterns of Pacific eolian samples compared to the range (shaded region) of loess samples from different continents (see Fig. 2 for data source). NS $=$ north-south transect of samples in northwest Pacific; EW $=$ eastwest transect of samples in north Pacific; all others represent individual site locations in equatorial Pacific. Relative to loess, these sediments are generally depleted in light REEs and exhibit positive $\mathrm{Eu}_{\mathrm{n}} / \mathrm{Sm}_{\mathrm{n}}$ ratios.

studies of both north and equatorial Pacific sediments do suggest that the depleted REE patterns may reflect the contamination of the ODED fraction, with volcanic materials having a composition more similar to that of average oceanic crust. For example, the mineralogy of sediments from five of the same north Pacific cores we have analyzed includes an assemblage (smectite, chlorite, plagioclase) which reflects andesitic volcanic material from Japan (LEINEN, 1989). Similarly, ZIMMERMAN (1982) has found significant amounts of nontronite in his analyses of equatorial sediments from Site 503B. Nontronite is a poorly crystalline, Fe-rich, authigenic smectite which forms through the low-temperature reaction of Fe-oxyhydroxides (produced from seafloor hydrothermal activity) with silica (bingenic opal) and is ohserved in marine sediments from throughout the Pacific (e.g., HEATH and DYMOND, 1977: Bauer Basin; HEIN et al., 1979: north equatorial Pacific; Murnane and Clague, 1983: Juan de Fuca Ridge; SINGER et al., 1984: southwestern Pacific basin) and Atlantic oceans (HOFFERT et al., 1978). The samples analyzed here are from geographic locations which may receive a substantial input of volcanic material from regional sources; for example, Site 503B is located on the north flank of the hydrothermally active Galapagos Ridge (PRELL et al., 1982), and the northwest Pacific samples are located downwind from the prevailing Westerlies which pass over Japan.

The geochemical data support the hypothesis that the ODED fraction of the sediments can be represented as a twocomponent system consisting of loess and volcanic residues. This is evident in a plot of the geochemical data using the La-Sc-Th system (Fig. 4). This type of plot is useful for distinguishing material derived from the upper versus oceanic 
crust, because REEs, $\mathrm{Sc}$, and Th are relatively insoluble and are not significantly fractionated during weathering, erosion, transportation, and deposition (TAYLOR and MCLENNAN, 1985). 'T he plot (Fig. 4) of China loess samples (treated and untreated) coincides almost exactly with that of average upper crustal material, while the plots of the ODED sediment fractions fall along a mixing line between upper and oceanic crustal material. GOLDSTEIN et al. (1984) also argue that Pacific authigenic sediments can be modeled as a mixture of materials from the continents and oceanic volcanic activity, and they further note, on the basis of Sm/Nd ratios, that riverine and eolian erosion products do not reflect simple mixing of upper-crustal materials with weathered basalt prior to deposition in the oceans.

\section{Mixing Models}

We have used two separate and independent modelling approaches to examine the two-component mixing hypothesis. In the first of these, the objective Q-Mode factor analysis technique of LEINEN and PISIAS (1984) was used to identify both the number and the composition of geochemically significant endmembers in the ODED sediment fractions. This procedure identified two compositional endmembers (factors) which together account for $99 \%$ of the total variance in the data. The composition scores for these endmembers are reported in Table 2 and are plotted on a $\mathrm{La}-\mathrm{Sc}$ - Th ternary diagram in Fig. 4. Factor 2 is clearly geochemically similar to the oceanic crust. Factor 1 is interpreted as representing the upper crustal component. This interpretation is supported by mineral assemblages identified through $\mathrm{X}$-ray diffraction analysis of samples from several of the same north Pacific sites we have analyzed (see LEINEN, 1989 for more details).

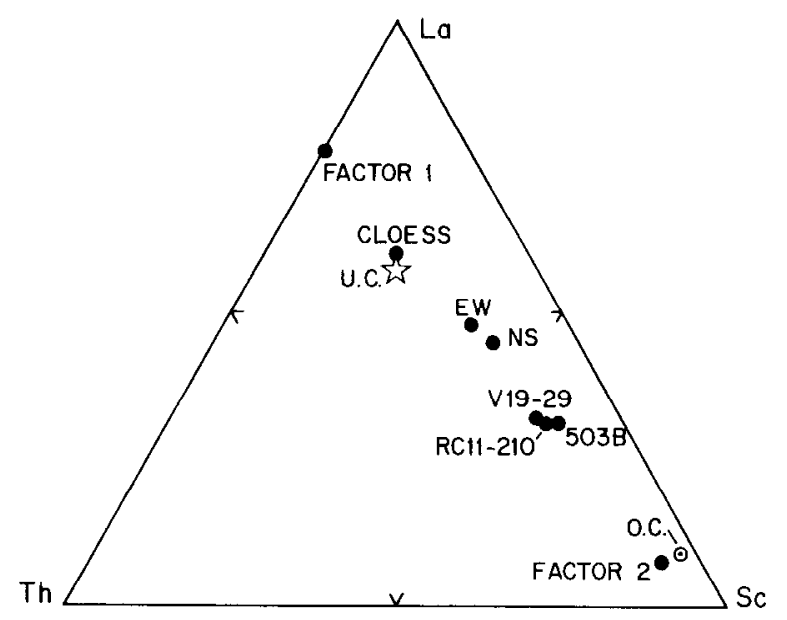

FIG. 4. La-Sc-Th ternary diagram showing the average composition of the upper crust (U.C.), oceanic crust (O.C.), extracted and unextracted China loess (CLoess), eolian sediments from the pelagic Pacific (see Fig. 3 for site ID codes), and Factors 1 and 2 derived from the Q-Mode factor analysis model. The average REE contents of these samples suggest mixing between two endmember components represented by the continental crust (Factor 1) and the oceanic crust (Factor 2). Data for U.C. and O.C. from TAYLOR and MCLENNAN (1985).

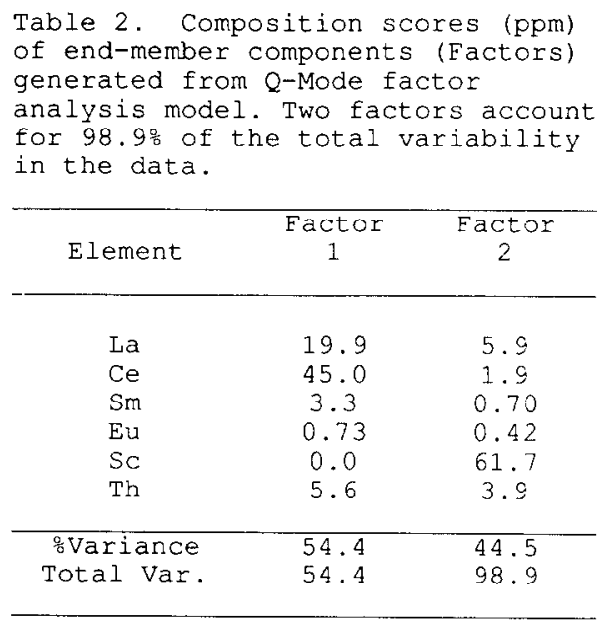

The composition of Factor 1 plots somewhat beyond the range of average upper crustal material; however, this is probably an artifact of the factor analysis procedure, which assigned all Sc to Factor 2.

The second modelling approach involved a normative analysis procedure. We assumed that the composition of the ODED fraction of each sample can be represented by some linear combination of two geochemical endmembers whose compositions are equivalent to that of average upper crustal and average oceanic crustal material, respectively (Table 3 ). In this case the bulk composition of each sample can be represented mathematically as an over-determined system of six equations (one for each element: $\mathrm{La}, \mathrm{Ce}, \mathrm{Sm}, \mathrm{Eu}, \mathrm{Sc}$, and $\mathrm{Th}$ ) in two unknowns (the relative amounts of each of the two endmembers) of the form (e.g., for La)

$$
S_{\mathrm{La}}=x_{1} U_{\mathrm{La}}+x_{2} O_{\mathrm{La}}+R_{\mathrm{La}}
$$

where $S_{\mathrm{La}}=$ the amount (ppm) of $\mathrm{La}$ in the sample, $U_{\mathrm{La}}$ and $O_{\mathrm{La}}=$ the average amount (ppm) of La in upper crustal material and oceanic crustal material, respectively (Table 3), $x_{1}$ and $x_{2}=$ the decimal fraction of material from the upper

\begin{tabular}{|c|c|c|}
\hline \multicolumn{3}{|c|}{$\begin{array}{l}\text { Table } 3 \text {. Average concentration } \\
\text { (ppm) of material from the upper } \\
\text { crust (UC) and oceanic crust (OC) } \\
\text { (frum Tdylor and McLennan, } 1985 \text {, } \\
\text { Tables } 2.15,11.6 \text { ). Data used as } \\
\text { end-member values in normative } \\
\text { analysis modcl. }\end{array}$} \\
\hline Filement. & Uc & oc \\
\hline La & 30 & 3.7 \\
\hline $\mathrm{Ce}$ & 64 & 11.5 \\
\hline $\mathrm{Sm}$ & 4.5 & 3.3 \\
\hline $\mathrm{Eu}$ & 0.88 & 1.3 \\
\hline $\mathrm{SC}$ & 11 & 38 \\
\hline $\mathrm{Th}_{\mathbf{L}}$ & 10.7 & 0.22 \\
\hline
\end{tabular}


Table 4. Predicted amount (wt. $\frac{0}{5}$ ) of upper crustal and oceanic crustal material in the eolian fraction of Pacific sediment samples. Factor 1 = upper crust; Factor 2 = oceanic crust. Dashed lines: samples not used in model.

\begin{tabular}{|c|c|c|c|c|}
\hline & Upper & Oceanic & f'actor & Factor \\
\hline Sample ID & Crust $\frac{\circ}{0}$ & Crust 号 & $1 \%$ & \\
\hline $\mathrm{RC} 11-210: 135-256$ & 55.75 & 44.25 & 70.64 & 29.36 \\
\hline $\mathrm{RC} 11-210: 264-304$ & 45.27 & 54.73 & 64.82 & 35.18 \\
\hline $\operatorname{RC} 11-210: 312-400$ & 47.96 & 52.04 & 66.39 & 33.61 \\
\hline RC $11-210: 408-472$ & 47.79 & 52.21 & 66.29 & 33.71 \\
\hline $\mathrm{RC} 11-210: 480-544$ & 44.00 & 56.00 & 64.07 & 35.93 \\
\hline RC11-210:552-608 & 48.92 & 51.08 & 66.94 & 33.06 \\
\hline $\mathrm{RC} 11-210: 616-720$ & 41.95 & 58.05 & 62.82 & 37.18 \\
\hline$R C 11-210: 728-816$ & 17.31 & 82.69 & 44.72 & 55.28 \\
\hline $\mathrm{RC} 11-210: 824-880$ & 8.28 & 91.72 & 36.24 & 63.76 \\
\hline RC11-210:888-1008 & 36.91 & 63.09 & 59.60 & 40.40 \\
\hline $\mathrm{RC} 11-210: 1016-1064$ & 43.89 & 56.11 & 64.00 & 36.00 \\
\hline RC11-210:1072-1136 & 32.00 & 68.00 & 56.25 & 43.75 \\
\hline RC11-210:1144-1200 & 26.35 & 73.65 & 52.10 & 47.90 \\
\hline RC $11-210: 1208-1280$ & 22.32 & 77.68 & 48.93 & 51.07 \\
\hline RC $11-210: 1288-1328$ & 29.00 & 71.00 & 54.09 & 45.91 \\
\hline RC11-210:1336-1376 & 32.93 & 67.07 & 56.90 & 43.10 \\
\hline $503 \mathrm{~B}-57$ & 37.68 & 62.32 & 60.11 & 39.89 \\
\hline $503 \mathrm{~B}-116.5$ & 31.18 & 68.82 & 55.67 & 44.33 \\
\hline $503 B-196 a$ & 29.09 & 70.91 & 54.16 & 45.84 \\
\hline $503 \mathrm{~B}-196 \mathrm{~b}$ & 30.40 & 69.60 & 55.11 & 44.89 \\
\hline $503 B-306$ & 46.03 & 53.97 & 65.27 & 34.73 \\
\hline $503 B-398$ & 21.63 & 78.37 & 48.37 & 51.63 \\
\hline $503 B-474$ & 35.99 & 64.01 & 58.99 & 41.01 \\
\hline $503 B-518$ & 24.79 & 75.21 & 50.90 & 49.10 \\
\hline V20-122:10 & 50.49 & 49.51 & 67.81 & 32.19 \\
\hline $\mathrm{V} 20-122: 2.7$ & 42.13 & 57.87 & 62.93 & 37.07 \\
\hline $\mathrm{V} 20-122: 80$ & 68.48 & 31.52 & 76.79 & 23.21 \\
\hline V20-122: 107 & 74.23 & 25.77 & 79.30 & 20.70 \\
\hline $\mathrm{V} 20-126: 18.5 \mathrm{a}$ & --- & --- & $\ldots$ &.-- \\
\hline V20-126:41.5b & 62.65 & 37.35 & 74.08 & 25.92 \\
\hline $\mathrm{V} 20-126: 115 a$ & ---- & --- & ---- & ---- \\
\hline$V 20-126: 115 b$ & ---- & ---- & ---- & ---- \\
\hline V20-126:149 & ---- & $-\cdots$ & --- & $-\cdots$ \\
\hline RC14-105:11a & 71.97 & 28.03 & 78.33 & 21.67 \\
\hline RC $14-105: 34.5$ & 70.45 & 29.55 & 77.67 & 22.33 \\
\hline RC14-105:111a & 81.21 & 18.79 & 82.14 & 17.86 \\
\hline $\mathrm{RC} 14-105: 147$ & ---- & ---- & ---- & ---- \\
\hline $\mathrm{V} 20-129: 11 \mathrm{a}$ & 74.33 & 25.67 & 79.34 & 20.66 \\
\hline$V 20-129: 45 a$ & 63.71 & 36.29 & 74.59 & 25.41 \\
\hline V20-129:139.5a & 77.78 & 22.22 & 80.77 & 19.23 \\
\hline $\mathrm{V} 20-129: 185$ & ---- & ---- & ---- & --- \\
\hline V28-294:1 & 47.20 & 52.80 & 65.95 & 34.05 \\
\hline V28-294:16a & 58.86 & 41.14 & 72.22 & 27.78 \\
\hline V32-128:10 & 96.87 & 3.13 & 87.82 & 12.18 \\
\hline V32-128:21 & 94.91 & 5.09 & 87.16 & 12.84 \\
\hline GPC $3-50833$ & 84.55 & 15.45 & 83.43 & 16.57 \\
\hline W8209B-1GC-a & 74.80 & 25.20 & 79.54 & 20.46 \\
\hline W8209B-1GC-b & 72.07 & 27.93 & 78.37 & 21.63 \\
\hline W8 209B-10GC-a & 62.64 & 37.36 & 74.08 & 25.92 \\
\hline W8 $209 \mathrm{~B}-10 \mathrm{GC}-\mathrm{b}$ & 63.20 & 36.80 & 74.35 & 25.65 \\
\hline W8209B-1 9GC-a & 64.11 & 35.89 & 74.78 & 25.22 \\
\hline W8209B-19GC-b & 63.57 & 36.43 & 74.52 & 25.48 \\
\hline W8 $209 B-21 G C$ & 71.15 & 28.85 & 77.97 & 22.03 \\
\hline $\operatorname{TT} 67476$ & 55.67 & 44.33 & 70.59 & 29.41 \\
\hline $\operatorname{TT} 67477$ & 72.43 & 27.57 & 78.53 & 21.47 \\
\hline V19-29:2.5 & 42.05 & 57.95 & 62.88 & 37.12 \\
\hline V19-29:132 & 35.64 & 64.36 & 58.76 & 41.24 \\
\hline
\end{tabular}


crust and oceanic crust, respectively, in the sample, and $R_{\mathrm{La}}$ = a residual error term. Each system of equations for each sample is solved by a linear programming procedure (e.g., DYMOND, 1981; ChVATAL, 1983) which minimizes the residual terms and calculates an optimal solution for the $x_{1}$ and $x_{2}$ values for each sample (Table 4).

The results of the two models were compared in a second run of the normative analysis model, in which we assumed the compositions of the two endmembers were equivalent to the composition scores generated by the factor analysis model (Table 2). The observed linear correlation between the $x_{1}$ and $x_{2}$ values of the two models is highly significant ( $p$-value $<0.0000$ ), and supports the hypothesis that the composition of the ODED sediment fractions can be represented as a twocomponent mixture of upper crustal and oceanic crustal endmembers. The non-zero intercepts in Fig. 5 suggest a systematic error; i.e., either model may systematically over- or underestimate the relative proportions of the two endmembers. However, both models are in excellent agreement with respect to identifying samples that contain the highest and lowest proportions of upper and lower crustal material. Be-
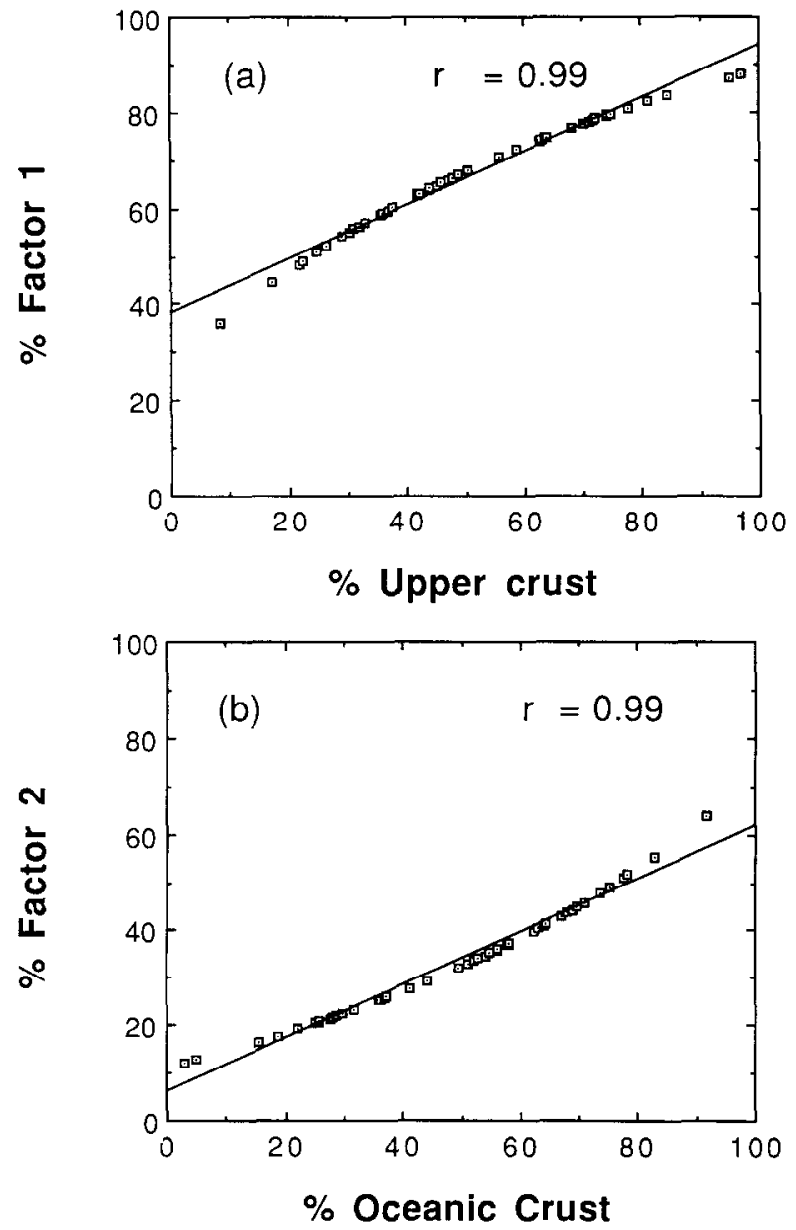

FlG. 5. Scatter plot of (a) the relative amount of Factor 1 predicted by factor analysis versus the amount of upper crustal material predicted from the normative analysis model, and (b) the relative amount of Factor 2 predicted by factor analysis versus amount of oceanic crustal material predicted from the normative analysis model. cause the choice of one model over the other is arbitrary, the following discussion is based on values generated by the factor analysis model (which makes no a priori assumptions about endmember compositions). Summary statistics show that the following percentages of each element are accounted for in the factor analysis model: $\mathrm{La}=95 \%, \mathrm{Ce}=100 \%, \mathrm{Sm}=81 \%$, $\mathrm{Eu}=68 \%, \mathrm{Sc}=100 \%$, and $\mathrm{Th}=82 \%$.

The results of the factor analysis model (Table 5) indicate that the ODED fraction of Pacific sediments contains significant amounts of material that has a composition similar to that of average oceanic crust. The geochemistry (this study) and mineralogy (LEINEN, 1989; ZIMMERMAN, 1982) of this material suggest it is derived from various sources, including ash from circum-Pacific volcanism, weathering products from islands and continental arcs (e.g., andesitic soil from Japan (LEINEN, 1989), and seafloor hydrothermal activity. The oceanic crustal component comprises about $22-25 \%$ of the north Pacific samples and about $39-44 \%$ of the equatorial Pacific samples. GoLDSTEIN and O'NIONS (1981) have estimated the contribution of volcanogenic neodymium in the Pacific using ${ }^{143} \mathrm{Nd} /{ }^{144} \mathrm{Nd}$ ratios and conclude that approximately $25 \%$ of the total $\mathrm{Nd}$ in pelagic clays of the western Pacific is derived from circum-Pacific volcanic activity. This value, if representative of all REEs, is in excellent agreement with our results for the north Pacific. The relatively higher amounts of this component in the equatorial samples may reflect significant hydrothermal inputs, at least for the two easternmost sites (503B and V19-29) which are located near the East Pacific Rise (EPR) and thus may not be generally representative for the equatorial Pacific. We note, however, that samples from the equatorial site at RC11-210, located about $3800 \mathrm{~km}$ from the crest of the EPR, also contain a significantly higher amount (39\%) of the oceanic crustal endmember relative to the north Pacific sites.

\section{Implications for Paleoclimatic Reconstructions}

Most samples analyzed in this study have been previously used to infer various aspects of paleoclimate (north Pacific cores V20-122, V20-126, RC14-105, V20-129, V28-294: REA and LEINEN, 1988; Core RC1 1-210: CHUEY et al., 1987; and DSDP Site 503B: REA et al., 1986). Inasmuch as circumPacific volcanic and hydrothermal activity presumably are not induced by perturbations in climate, the incorporation of these materials in pelagic sediments and their survival during the chemical extraction process are of particular relevance to paleoclimatic interpretations. In the following sections we attempt to assess the significance of our results with respect to these earlier studies.

\section{Glacial/interglacial variations of eolian components}

REA et al. (1991) have summarized studies of the late Quaternary eolian dust flux to the pelagic Pacific Ocean. Dust flux in the northwest Pacific is generally higher during glacial times relative to interglacial stages (HovaN et al., 1989), while the opposite relationship is observed in the equatorial Pacific south of the Intertropical Convergence Zone (ITCZ). During the past 300,000 years the eolian flux south of the ITCZ is greatest during inter-glacial stages. We examined these 


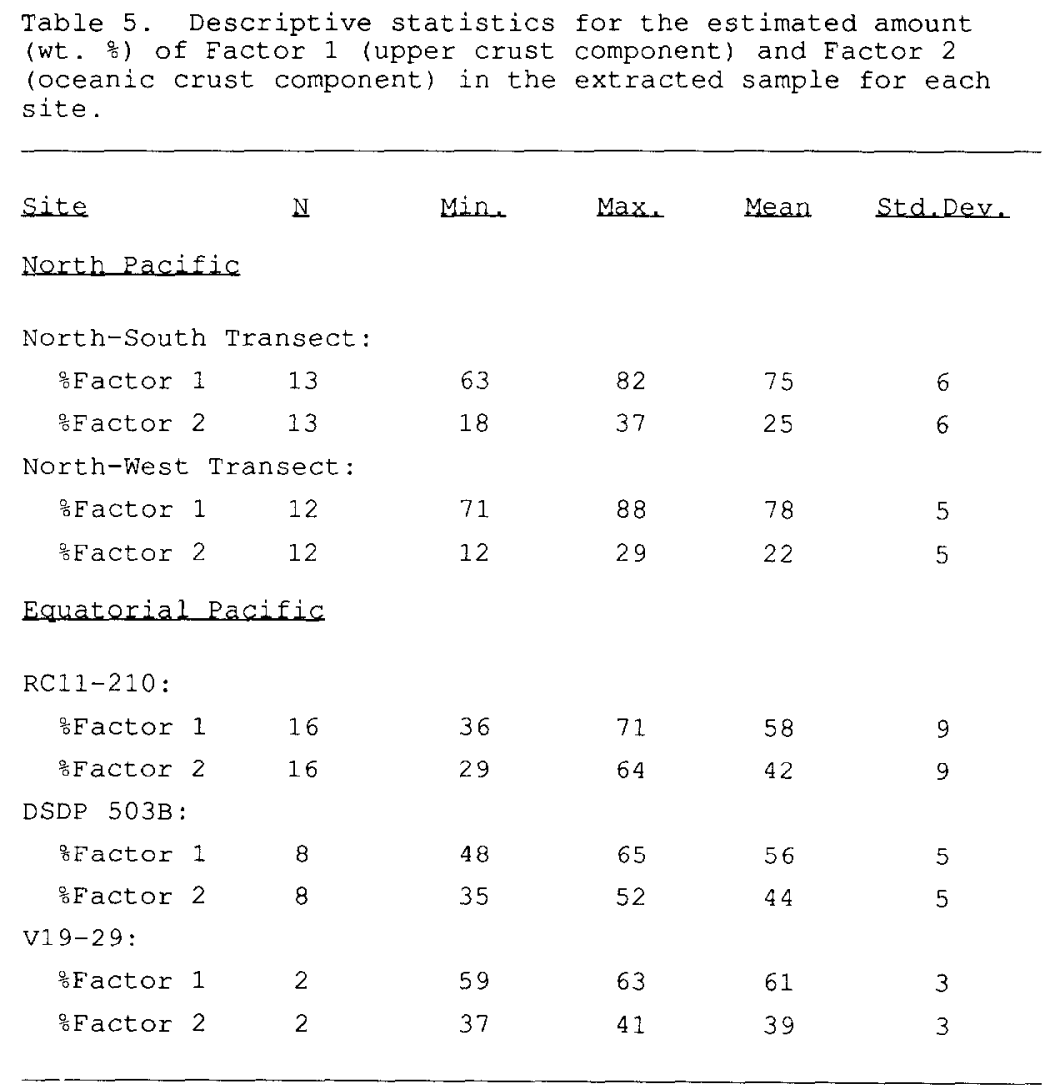

relationships using corrected eolian mass accumulation rate $\left(\right.$ EMAR $_{\text {corr }}$ ) values for 13 samples from the northwest Pacific previously discussed by REA and LEINEN (1988), and for 8 samples from DSDP 503B in the equatorial Pacific (REA ct al., 1986). The EMAR corr $_{\text {values (Table 6) were calculated as }}$ the product of the total eolian MAR and the fractional amount of continental material (Factor 1) in the sample. In general, the results obtained using the EMAR $\mathrm{R}_{\text {corr }}$ values are consistent with previous interpretations. The EMAR $\mathrm{R}_{\text {corr }}$ values are greater during glacial times in the northwest Pacific, but are greater during interglacial times in the equatorial Pacific. However, the observed differences between glacial and interglacial times in both cases are not statistically significant ( $p$ value $\geq 0.24$ ) based on a non-parametric two sample test (Wilcoxon Rank Sum). This may reflect the small sample sizes involved in the analysis. Statistically significant (Wilcoxon Rank Sum) glacial versus interglacial differences are observed for light REE concentrations ( $\mathrm{La}, \mathrm{Ce}, \mathrm{Sm}, \mathrm{Eu}$ ) despite the small sample sizes. As shown in Fig. 6, northwest Pacific samples are enriched in light REEs during glacial intervals $(p$-value $=0.05)$, and equatorial samples $(\mathrm{RC} 11-210)$ are enriched in light REEs during interglacial stages ( $p$-value $=0.07$ ). No statistically significant differences were found for the light REE composition of 503B samples nor for the heavy REEs regardless of the site or statistical method used (Wilcoxon Rank Sum, Student's $t$ test). These results support

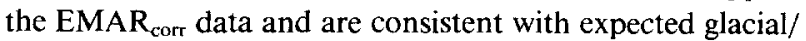
interglacial changes in the REE composition of the sediments. For example, the light REEs ( $\mathrm{La}$ and $\mathrm{Ce}$ ) are enriched in average upper crustal material relative to average oceanic crust, whereas the heavy REEs ( $\mathrm{Yb}$ and $\mathrm{Lu}$ ) are depleted in the upper crust (Table 3). Thus, during times of increased eolian flux from the continents, a greater increase in the light REE content relative to heavy REEs should be exhibited in the sediment assemblage.

\section{Latitudinal variations}

LEINEN (1989) examined samples taken from the same locations we have analyzed to determine the geographical flux distribution of continentally derived eolian minerals along the north-south transect in the northwest Pacific. For equivalent time intervals along this transect, the highest eolian flux occurs between $35^{\circ} \mathrm{N}$ and $42^{\circ} \mathrm{N}$, downwind from the central Asian source region. The eolian flux diminishes markedly both north and south of this range (REA and LEINEN, 1988). Our results are consistent with these mineralogical studies: both the fractional amount of continentally derived material (Factor 1) and the EMAR maximum values between $36^{\circ} \mathrm{N}$ and $42^{\circ} \mathrm{N}$ (Table 7). Because of the glacial vs. interglacial differences previously discussed, only those samples from interglacial periods (except V32128:10.0) were used to construct the distribution pattern. Differences between northern versus southern hemisphere eolian accumulation are discussed by RFA et al. (1991), who estimate that the total eolian mass accumulation rate spans three orders of magnitude between sites in the pelagic Pacific. In general, the EMAR of the north Pacific $>$ equatorial Pacific $>$ south Pacific. Differences in the REE content and EMAR corr $_{\text {values }}$ between north and equatorial Pacific samples are consistent 
Table 6. Grain size and corrected eolian mass accumulation rate (EMARcorr) data for pacific eolian samples. Grain size data and original eolian MAR data from Rea et al., 1986 (503B); Rea and Leinen, 1988, (Cores V20, RC14, V28); and Chuey et al., 1987 (RC11-210). EMAR corr values: this study. See Table 1 for Site ID and glacial period codes.

\begin{tabular}{|c|c|c|c|c|c|c|}
\hline Sample ID & $\begin{array}{c}\text { Depth } \\
\text { (cm) }\end{array}$ & $\begin{array}{l}\text { Site } \\
\text { ID }\end{array}$ & $\begin{array}{l}\text { Glacial } \\
\text { Period }\end{array}$ & $\begin{array}{l}\text { Phi } \\
\text { Size }\end{array}$ & $\begin{array}{l}\text { Grain } \\
\text { Size } \\
(\mu \mathrm{m})\end{array}$ & $\begin{array}{c}\text { EMAR } \operatorname{corr} \\
\left(\mathrm{mgcm}^{-2} \mathrm{ky}^{-1}\right)\end{array}$ \\
\hline RC1 1-210: 135-256 & 195 & 1 & - & 8.27 & 3.24 & 7.69 \\
\hline RC1 $1-210: 264-304$ & 284 & 1 & 2 & 8.28 & 3.22 & 17.3 \\
\hline$R C \perp 1-210: 312-400$ & 356 & $\perp$ & 1 & 8.33 & 3.11 & 11.2 \\
\hline RC1 1-210:408-472 & 440 & 1 & 2 & 8.41 & 2.94 & 20.2 \\
\hline RC1 1-210:480-544 & 512 & 1 & 1 & 7.88 & 4.24 & 26.0 \\
\hline $\operatorname{RC1} 1-2 \pm 0: 552-608$ & 580 & 1 & 2 & 8.44 & 2.88 & 14.3 \\
\hline RC1 1-210:616-720 & 658 & 1 & 1 & 8.29 & 3.20 & 15.4 \\
\hline RC11-210:728-816 & 772 & 1 & - & 8.51 & 2.74 & 6.88 \\
\hline$R C 11-210: 824-880$ & 852 & 1 & - & 8.19 & 2.78 & 16.5 \\
\hline RC11-210:888-1008 & 948 & 1 & 1 & 8.28 & 3.22 & 13.6 \\
\hline RC11-210:1016-1064 & 1040 & 1 & - & 8.56 & 2.65 & 15.2 \\
\hline RC11-210:1072-1136 & 1104 & 1 & - & 8.59 & 2. .60 & 2.7 .5 \\
\hline RC11-210:1144-1200 & 1172 & 1 & 1 & 8.41 & 2.94 & 11.6 \\
\hline $\mathrm{RC} 11-210: 1208-1280$ & 1244 & 1 & - & 8.28 & 3.22 & 10.2 \\
\hline RC11-210:1288-1328 & 1308 & 1 & - & 8.92 & 2.06 & 11.8 \\
\hline RC11-210:1336-1376 & 1356 & 1 & - & 8.98 & 1.98 & 9.86 \\
\hline $503 \mathrm{~B}-57$ & 57 & 2 & 1 & 8.62 & 2.54 & 29.0 \\
\hline $503 B-116.5$ & 116.5 & 2 & 2 & 8.52 & 2.72 & 54.4 \\
\hline $503 \mathrm{~B}-196 \mathrm{a}$ & 196 & 2 & 1 & 8.63 & 2.52 & 31.6 \\
\hline $503 \mathrm{~B}-1.96 \mathrm{~b}$ & 196 & 2 & 1 & 8.63 & 2.52 & 32.2 \\
\hline $503 \mathrm{~B}-306$ & 306 & 2 & 2 & 8.57 & 2.63 & 71.3 \\
\hline $503 B-398$ & 398 & 2 & 2 & 8.68 & 2.44 & 23.4 \\
\hline $503 B-474$ & 474 & 2 & 1 & 8.74 & 2.34 & 31.9 \\
\hline $503 B-518$ & 518 & 2 & 2 & 8.64 & 2.51 & 68.5 \\
\hline $\mathrm{V} 20-122: 10$ & 10 & 3 & 2 & 8.33 & 3.11 & 329 \\
\hline$V 20-122: 27$ & 27 & 3 & 2 & 8.47 & 2.82 & 484 \\
\hline $\mathrm{V} 20-122: 80$ & 80 & 3 & 1 & 8.36 & 3.04 & 499 \\
\hline $\mathrm{V} 20-122: 107$ & 107 & 3 & 1 & 8.47 & 2.82 & 722 \\
\hline$v 20-126: 18.5 a$ & 18.5 & 3 & 2 & 8.38 & 3.00 & -- \\
\hline $\mathrm{V} 20-126: 41.5 \mathrm{~b}$ & 41.5 & 3 & 2 & 8.11 & 3.62 & 761 \\
\hline $\mathrm{v} 20-126: 115 \mathrm{a}$ & 115 & 3 & 1 & -- & -- & --- \\
\hline V20-126:115b & 115 & 3 & 1 & -- & -- & --- \\
\hline V20-126:149 & 149 & 3 & 1 & 8.48 & 2.80 & --- \\
\hline RC1 4-105:11a & 11 & 3 & 2 & 8.30 & 3.17 & 741 \\
\hline RC14-105:34.5 & 34.5 & 3 & 2 & 7.99 & 3.93 & 1300 \\
\hline RC14-105:111a & 111 & 3 & 1 & 8.45 & 2.86 & 595 \\
\hline RC1 4-105:147 & 147 & 3 & 1 & 8.26 & 3.26 & --- \\
\hline $\mathrm{v} 20-129: 11 \mathrm{a}$ & 11 & 3 & 2 & 8.23 & 3.33 & 792 \\
\hline $\mathrm{V} 20-129: 45 \mathrm{a}$ & 45 & 3 & 2 & 8.07 & 3.72 & 1190 \\
\hline V20-129:139.5a & 139.5 & 3 & 1 & 8.40 & 2.96 & 861 \\
\hline $\mathrm{V} 20-129: 185$ & 185 & 3 & 1 & 8.33 & 3.11 & --- \\
\hline V28-294:1 & 1 & 3 & 2 & 8.19 & 3.42 & 36.3 \\
\hline $\mathrm{V} 28-294: 16 \mathrm{a}$ & 16 & 3 & 2 & 8.10 & 3.64 & 152 \\
\hline
\end{tabular}

with this observation. For example, our results show that north Pacific sediments are generally enriched in REEs (i.e., closer to upper crustal values, Fig. 3 ) and contain higher values (Table 6) relative to equatorial samples.

\section{Grain size correlations}

Spectral analysis of median grain size in pelagic sediments has been used as a proxy indicator of past climate variations (JANECEK and REA, 1985; Pisias and REA, 1988). Our results suggest that the two compositional endmembers are characterized by significantly different median grain sizes; consequently, compositional differences among samples may influence paleoclimate interpretations based upon these data. In Fig. 7 the median grain size of the ODED component is plotted as a function of \% Factor 1 for 41 samples from the northwest and equatorial (RC11-210, 503B) Pacific (EMAR data from CHUEY et al., 1987; REA and LEINEN, 1988; REA et al., 1986). These two variables are highly correlated ( $p$ value $=0.002$ ), and a linear regression predicts that sediments composed of $100 \%$ continental material correspond to a median grain diameter of $3.74 \mu \mathrm{m}$ (8.06 phi-units). The median grain size of the oceanic crustal endmember (i.e., $0 \%$ continental material) is predicted to be $1.61 \mu \mathrm{m}$ (9.28 phi-units). In general, the grain size distributions of parent aerosols are highly variable and depend on the composition, source, and the distance over which the aerosol has traveled (PROSPERO et al., 1989). Although there is a paucity of aerosol data, Asian eolian dust collected over Japan had a mass median diameter of $4 \mu \mathrm{m}$ (KADOWAKI, 1979), in excellent agreement with our predicted value $(3.74 \mu \mathrm{m})$ based on the sediment geochemistry. These results are particularly relevant to paleoclimate studies, inasmuch as they suggest that the relative amount of the two geochemical endmembers will determine 


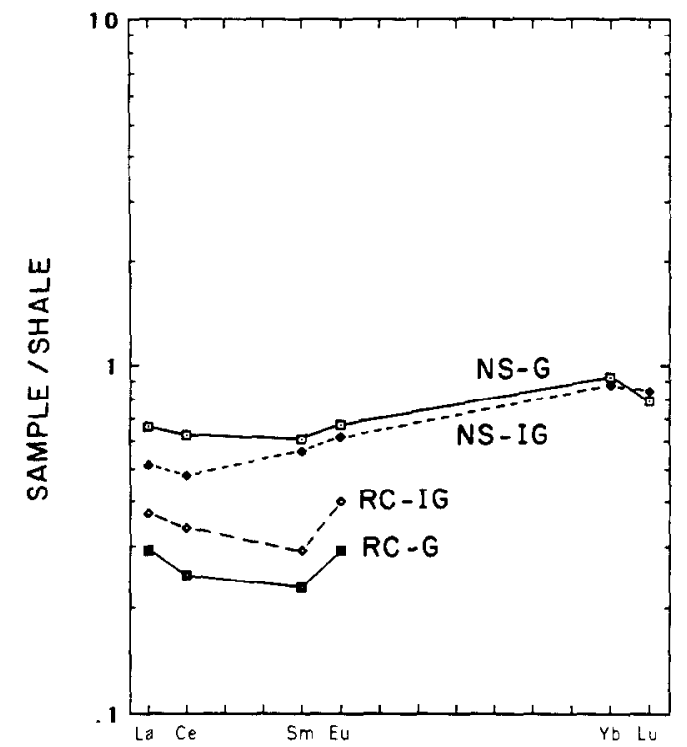

FIG. 6. Shale-normalized (GromET et al., 1984) glacial (G) versus inter-glacial (IG) variations in the REE content of the extracted sediments. On average, northwest Pacific samples (NS) are more enriched in REEs during glacial periods while equatorial samples (RC) are more enriched during interglacial periods.

the sediment median grain size. Thus, limitations imposed by the chemical extraction procedure might be minimized using the geochemical and geostatistical methods presented here to account for volcanogenic components. Similarly, the continental crustal signal can be maximized by examining only the larger size fraction $(>3 \mu \mathrm{m}$ ) of pelagic sediments.

Paleoclimatic variations in wind intensity and aridity (de-

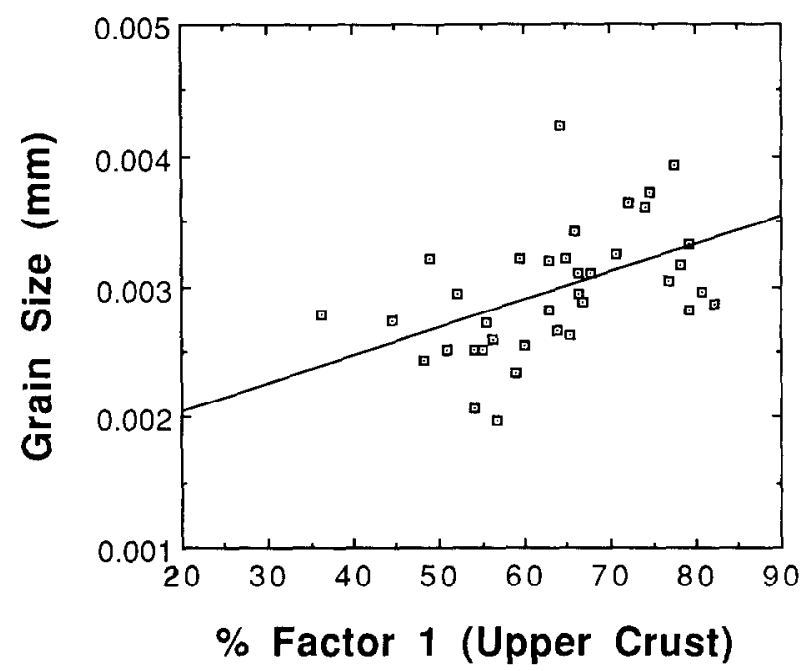

FiG. 7. Scatter plot of the amount of Factor 1 (continentally derived material) present in the extracted samples versus the median grain size. The positive correlation indicates that continental materials are most abundant in the larger grain sizes $\left(r^{2}=0.24, p\right.$-value $\left.=0.002\right)$.

gree of vegetative cover) are interpreted on the basis of median grain size and mass accumulation rate, respectively, of the eolian fraction. Such reconstructions assume that these two variables are independent (REA et al., 1985); i.e., each uniquely monitors either wind velocity or humidity. We tested this assumption (Fig. 8 ) by comparing EMAR corr $_{\text {values }}$ with their respective median grain sizes for northwest and equatorial Pacific samples. The results (Fig. 8) indicate a significant linear correlation exists between these two variables ( $p$-value $=0.0004)$. Consequently, we suggest that both of

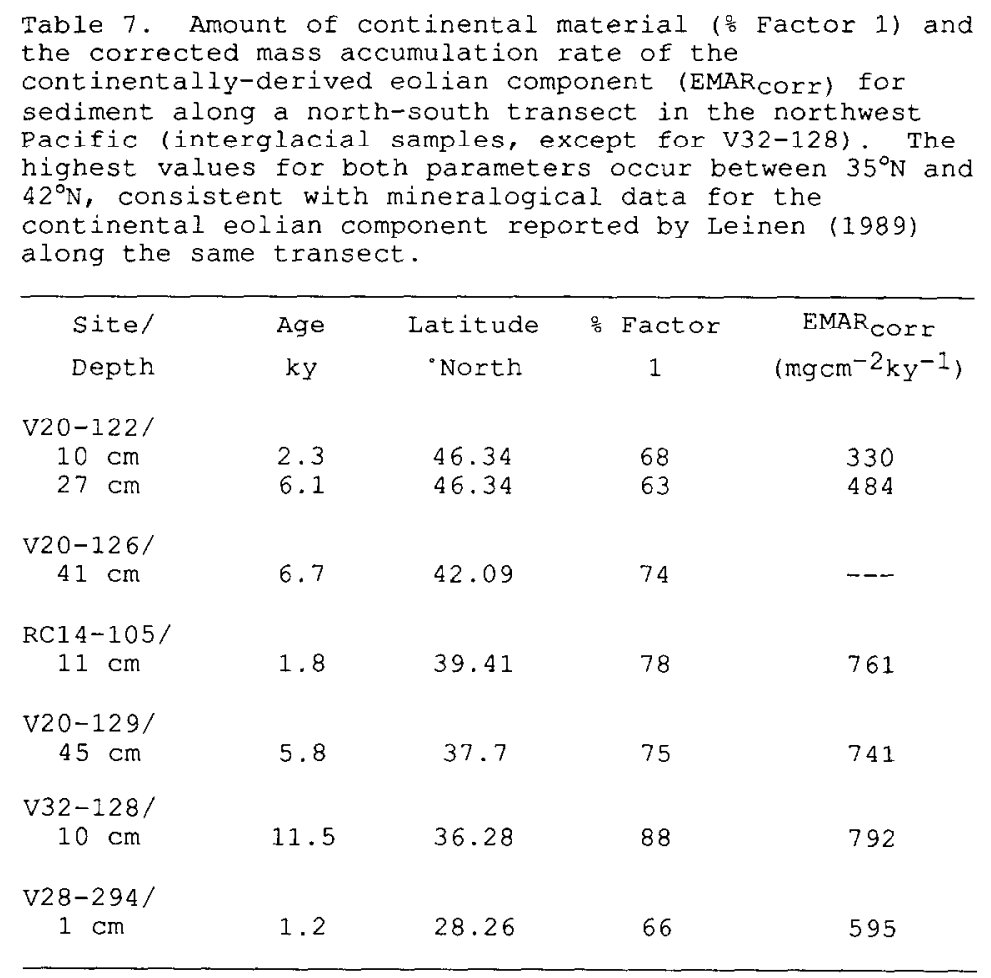




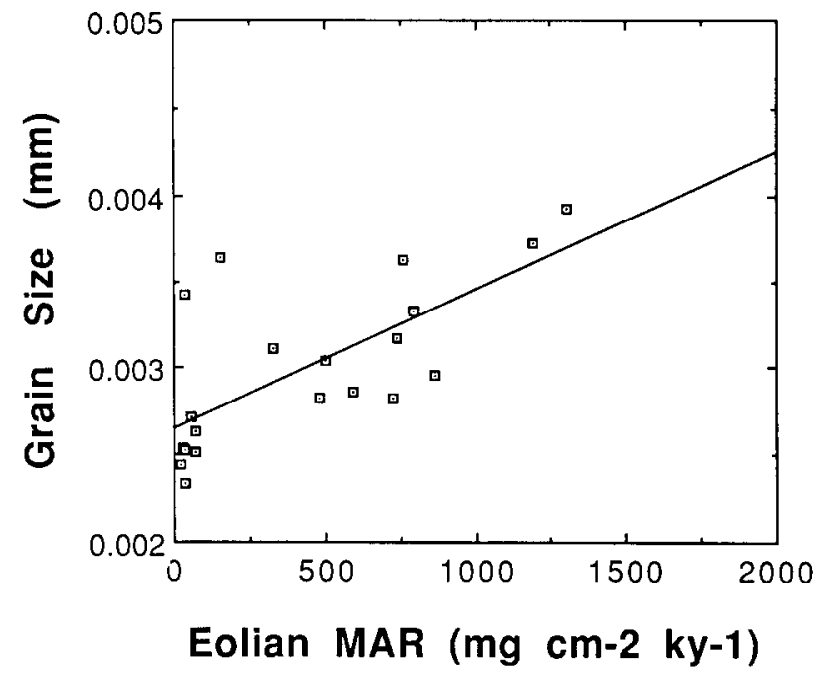

FIG. 8. Plot of the corrected eolian mass accumulation rate values and median grain size for selected extracted sediment samples from the northwest and equatorial Pacific. The linear correlation indicates that these two parameters may both reflect paleo-wind intensities $\left(r^{2}\right.$ $=0.50, p$-value $=0.0004$ )

these variables may reflect related properties of wind systems, and that this relationship may be analogous to the capacity and competence of a river. For example, the intensity of fluid flow determines the maximum grain size that the fluid can move, thus defining the fluid's competence (BLATT et al., 1980). Likewise, a river has a limited capacity (rate of sediment discharge per cross-sectional area of the stream) to transport material. Both capacity and competence depend on the intensity of fluid flow. Similarly, both the grain size (competence) and the mass accumulation rate (capacity) of the eolian component in marine sediments may reflect wind intensity.

\section{SUMMARY AND CONCLUSIONS}

A critical assumption underlying paleoclimatic interpretations based on grain size and MAR analyses of the ODED fraction of pelagic sediments is that it is composed exclusively of eolian-transported weathering products from the continents, such that these measurements can serve as valid paleoclimate indicators. We show, on the basis of mineralogical and geochemical analyses, that the ODED fraction of Pacific sediments actually contains two compositional endmembers: (1) an upper crustal component, likely the eolian-transported weathering products from the continents, and (2) an oceanic crustal component, which consists primarily of volcanogenic materials. The presence of significant amounts of volcanic materials in these samples is relevant, because the sample locations had been selected in previous palcoclimate studies with a view toward minimizing non-eolian and non-continental "contaminants" (e.g., hemipelagic sediments, icerafted debris). Inasmuch as volcanic activity is not a climatecontrolled process, the presence of abundant ash (approximately $12-64 \%$ ) will nonetheless influence the measured physical parameters (e.g., grain size and MAR) which are commonly used in paleoclimate interpretations.
Quantitative estimates of both endmember components were calculated on the basis of their geochemistry and were then used to refine continentally derived eolian flux data previously reported. North Pacific samples contain a higher proportion of continentally derived materials relative to the equatorial Pacific, consistent with the results of REA et al. (1991) who analyzed physical properties of the ODED fraction. This regional difference is also supported by REE abundance patterns: north Pacific sediments are generally enriched in REEs relative to equatorial samples, reflecting higher REE content in the upper-crustal endmember. We also observe a continental flux maximum between $36^{\circ} \mathrm{N}$ and $42^{\circ} \mathrm{N}$ for the north-south transect of samples in the northwest Pacific, which supports the results of LEINEN (1989) who analyzed the $<2$ micron fraction of samples from the same cores. Glacial vs. interglacial differences are also observed in our results. Both the light REE concentrations, and the corrected eolian MAK values (EMAR ${ }_{\text {corr }}$ ) are higher during glacial times in the north Pacific, and higher during interglacial times for equatorial samples south of the Intertropical Convergence Zone (ITCZ). Previous investigations of these samples are consistent with these glacial/interglacial differences.

The correlation we have found between median grain size and $\mathrm{EMAR}_{\text {corr }}$ contradicts the assumption of independence between these two parameters; thus, MAR data must be used with caution when making inferences about paleo-aridity in the continental source region. Both parameters might simply reflect variations in paleo-wind intensity. The significant correlation between the fractional amount of continental material in a given sample and the median grain size of the sample predicts that the volcanic ash component is predominantly fine-grained $(<2 \mu \mathrm{m}$, on the basis of this study). This result suggests that future paleoclimate studies that involve measurements of the physical properties of the ODED fraction can minimize contamination effects by examining only the larger size fraction ( $>3 \mu \mathrm{m}$ ) of pelagic sediments.

Acknowledgments-This research was supported in part by the $\mathrm{Na}$ tional Science Foundation under Grant No. OCE-8410034 to R. M. Owen. We are grateful to R. Cullers, S. McLennan, and an anonymous reviewer for comments and suggestions they offered based on a review of an earlier version of this paper.

Editorial handling: S. M. McLennan

\section{REFERENCES}

Blank M., Leinen M., and Prospero J. M. (1985) Major Asian aeolian inputs indicated by the mineralogy of aerosols and sediments in the western North Pacific. Nature 314, 84-86.

Blatt H., Middleton G., and Murray R. (1980) Origin of Sedimentary Rocks. Prentice-Hall.

Chuey J. M., Rea D. K., and Pisias N. G. (1987) Late Pleistocene paleoclimatology of the central Equatorial Pacific: A quantitative record of eolian and carbonate deposition. Quat. Res. 28, 323339.

Chvatal V. (1983) Linear Programming. W. H. Freeman.

DAMS R. and ROBBINS V. A. (1970) Nondestructive activation analysis of environmental samples. Great Lakes Res. Div., Tech. Rept. 48. Univ. of Michigan.

DYMOND J. (1981) Geochemistry of Nazca Plate surface sediments: An evaluation of hydrothermal, biogenic, detrital, and hydrogenous sources. Geol. Soc. Amer. Mem. 154, 133-174.

FERGuSON W. S., GRIFFIN J. J., and GoldBerg E. D. (1970) Atmospheric dusts from the North Pacific-A short note on long range eolian transport. J. Geophys. Res. 75, 1137-1139. 
Fox D. J. and GuIRE K. E. (1976) Documentation for MIDAS. 3d ed. The Statistical Research Laboratory, University of Michigan, Ann Arbor.

GoldsteIN S. L. and O'Nions R. K. (1981) Nd and Sr isotopic relationships in pelagic clays and ferromanganese deposits. Nature 292, 324-327.

Goldstein S. L., O'Nions R. K., and Hamilton P. J. (1984) $\Lambda$ $\mathrm{Sm}-\mathrm{Nd}$ isotopic study of atmospheric dusts and particulates from major river systems. Earth Planet. Sci. Lett. 70, 221-236.

Gurdon C. E., Randle K., Goles G. D., Corliss J. B., Beesen M. H. and OXLEY S. S. (1968) Instrumental activation analysis of standard rocks with high resolution x-ray detectors. Geochim. Cosmochim. Acta 32, 364-396.

GrifFIN J. J., WINDOM H., and GoldberG E. D. (1968) The distribution of clay mineral in the world ocean. Deep-Sea Res. 15, 433-459.

Gromet L. P., DYMEK R. F., HASKIN L. A., and KoroteV R. L. (1984) The "North American shale composite": Its compilation, major and trace element characteristics. Geochim. Cosmochim. Acta 48, 2469-2482.

Heath G. R. and Dymond J. (1977) Genesis and transformation of metalliferous sediments from the East Pacific Rise, Bauer Deep, and Central Basin, northwest Nazca Plate. Geol. Soc. Amer. Bull. 88, 723-733.

HEIN J. R., YEH H.-W., and AleXANDER E. (1979) Origin of ironrich montmorillonite from the manganese nodule belt of the north equatorial Pacific. Clays Clay Mineral. 27, 185-194.

Hoffert M., Perseil A., Hekinian R., Choukroune P., NeedhaM H. D., FrancheTeaU J., and Le PiChON X. (1978) Hydrothermal deposits sampled by diving saucer in Transform rault "A" near $37^{\circ} \mathrm{N}$ on the Mid-Atlantic Ridge, Famous Area. Ocean. Acta 1, 73-86.

Hovan S. A., Rea D. K., Pisias N. G., and Shackleton N. J. (1989) A direct link between the China Loess and Marine ${ }^{218} \mathrm{O}$ Records: Eolian flux to the North Pacific. Nature 340, 296-298.

JANECEK T. R. and REA D. K. (1985) Quaternary fluctuations in the Northern Hemisphere Trade Winds and Westerlies. Quat. Res. 24, 150-163.

KADOWAKI S. (1979) Silicon and aluminum in urban aerosols for characterization of atmospheric soil particles in the Nagoya area. Environ. Sci. Tech. 13, 1130-1133.

LEDBETTER M. T. (1985) Tephrochronology of marine tephra adjacent to Central America. Geol. Soc. Amer. Bull. 96, pp. 77-82.

LEINEN M. (1989) The Late Quaternary record of atmospheric transport to the northwest Pacific from Asia. In Paleoclimatology and Paleometerology: Modern and Past Patterns of Global Atmospheric Transport (eds. M. LEINEN et al.), pp. 693-732. D. Reidel.

LEINEN M. and PISIAS N. (1984) An objective technique for determining end-member compositions and for partitioning sediments according to their sources. Geochim. Cosmochim. Acta 48, 47-62.

Murnane R. and Clague D. A. (1983) Nontronite from a lowtemperature hydrothermal system on the Juan de Fuca Ridge. Earth Planet. Sci. Lett. 65, 343-352.

PISIAS N. G. and REA D. K. (1988) Late Pleistocene paleoclimatology of the central equatorial Pacific: Sea surface response to the southeast Trade Winds. Paleoceanography 3(1), 21-37.

PRell. W. L., et al. (1982) Site 503: Eastern Equatorial Pacific. Init. Repts. DSDP 68, 383-395.

PROSPERo J. M. (1981) Eolian transport to the world ocean. In The Sea (ed. C. EMILIANI), Vol. 7, pp. 801-874. J. Wiley \& Sons.

Prospero J. M., Uematsu M., and Savole D. L. (1989) Mineral Aerosol Transport to the Pacific Ocean. In Chemical Oceanography (ed. J. P. RILEY), Vol. 10.

REA D. K. (1982) Fuctuation in colian sedimentation during the past five glacial-interglacial cycles: A preliminary examination of data from Deep Sea Drilling Project Hole 503B, eastern equatorial Pacific. In Inil. Repts. DSDP 68, 409-415.

REA D. K. and JANECEK T. R. (1981) Mass accumulation rates of non-authigenic inorganic crystalline (eolian) component of deep sea sediments from the western Mid-Pacific Mountains, Deep Sea Drilling Project Site 463. In Init. Repts. DSDP 62, 653-659.

REA D. K. and LEINEN M. (1988) Asian aridity and the zonal westerlies: Late Pleistocene and Holocene record of eolian deposition in the northwest Pacific Ocean. Palaeogeography, Palaeoclimatology, Palaeoecology 66, 1-8.

REA D. K., LeINEN M., and JANECEK T. R. (1985) A geologic approach to the long-term history of atmospheric circulation. Science 227. 721-725.

Rea D. K., Chambers L. W., Chuey J. M., Janecek T. R., Leinen M., and PISIAS N. G. (1986) A 420,000-year record of cyclicity in oceanic and atmospheric processes from the eastern Equatorial Pacific. Paleoceanography 1, 577-586.

REA D. K., Hovan S. A., and JANECEK T. R. (1991) Late Quaternary flux of eolian dust to the pelagic ocean. In Global Sedimentary Geofluxes (ed. W. W. HAY). National Academy of Science, National Research Council (in press).

Singer A., Stoffers P., Ieller-Kallai L., and Szafranek D. (1984) Nontronite in a deep-sea core from the south Pacific. Clays Clay Mineral. 32(5), 375-383.

TAylor S. R. and McLennan S. M. (1985) The Continental Crust: Its Composition and Evolution. Blackwell.

TAYLOR S. R., MCLENNAN S. M., and MCCulloCh M. T. (1983) Geochemistry of loess, continental crustal composition and crustal model ages. Geochim. Cosmochim. Acta 47, 1897-1905.

TUNGSHENG L. et al. (1985) Loess and the Environment. China Ocean Press, Beijing.

WinDOM H. L. (1969) Atmospheric dust records in permanent snowfields: Implications to marine sedimentation. Geol. Soc. Amer. Bull. 80, 761-782.

WINDOM H. L. (1976) Lithogenous material in marine sediments. In: Chemical Oceanography (eds. J. P. RILEY and R. CHESTER), Vol. 5, 2d ed., pp. 103-135. Academic Press.

ZHENG HONG-HAN (1984) Paleoclimatic events recorded in clay minerals in loess of China. In Lithology and Stratigraphy of Loess and Paleosols (ed. M. PESCI), pp. 171-181. Geographic Research Institute, Hungarian Academy of Sciences, Budapest.

ZIMMERMAN H. B. (1982) Lithologic stratigraphy and clay mineralogy of the western Caribbean and eastern Equatorial Pacific, Leg 68, Deep Sea Drilling Project. In Init. Repts. DSDP 68, 383-395. 